Article

\title{
Inclusive Leadership: Good Managerial Practices to Address Cultural Diversity in Schools
}

\author{
Inmaculada Gómez-Hurtado ${ }^{1, *}$, René Valdés ${ }^{2}$, Inmaculada González-Falcón ${ }^{1}$ and Felipe Jiménez Vargas ${ }^{3}$ \\ ${ }^{1}$ Department of Pedagogy, University of Huelva, Spain; E-Mails: inmaculada.gomez@dedu.uhu.es (I.G.-H.), \\ inmaculada.gonzalez@dedu.uhu.es (I.G.-F.) \\ ${ }^{2}$ Faculty of Education and Social Sciences, Andres Bello University, Chile; E-Mail: rene.valdes@unab.cl \\ ${ }^{3}$ Faculty of Health and Social Sciences, University of the Americas, Chile; E-Mail: fjimenez@udla.cl \\ * Corresponding author
}

Submitted: 15 June 2021 | Accepted: 28 July 2021 | Published: 13 October 2021

\begin{abstract}
Educational inclusion of foreign pupils has become a priority objective in recent years in many countries worldwide. Attending to the cultural diversity of pupils and providing an inclusive educational response is now a main goal of education systems. In this context, educational leadership is a key factor for school improvement. Management teams face the difficult mission of responding to the diversity of people that make up the educational community in a scenario marked by the expansive increase in migrant families and the scarcity of inclusive and intercultural government programmes. This article explores good management practices for cultural diversity management in six early childhood and primary education centres in Spain and Chile from an inclusive leadership approach. Factors that influence the development of inclusive leadership and the process deployed to carry out diversity management are examined. Through a qualitative methodology, six case studies were carried out using the interview, participant observation, and document analysis as instruments. The main outcomes show the importance of leaders in promoting an inclusive collaborative culture, in classroom practices focused on the knowledge and cultural capital of foreign pupils, the development of organisational and didactic strategies based on the recognition and participation of the educational community, its commitment to social justice, a management of diversity based on collaboration, and a shared concept of educational inclusion. The conclusions show four common dimensions in the good practices of each country: professional development of the community, school participation, inclusive school culture, and positive management of diversity.
\end{abstract}

\section{Keywords}

cultural diversity; diversity in schools; inclusive leadership; management teams

\section{Issue}

This article is part of the issue "Promoting Inclusion and Equality in Education" edited Allen Thurston (Queen's University Belfast, UK) and Tien-Hui Chiang (Anhui Normal University, China).

(C) 2021 by the authors; licensee Cogitatio (Lisbon, Portugal). This article is licensed under a Creative Commons Attribution 4.0 International License (CC BY).

\section{Introduction}

Responding to the diversity of migrant students and building inclusive schools are nowadays essential needs for the different education systems worldwide. Inclusive education has thus become an essential issue in the international scope (Ainscow, 2020). Specifically, goal 4 of the 2030 agenda for sustainable development calls upon us to ensure inclusive and equitable quality education and promote lifelong learning opportunities for all (Agenda $2030,2015)$. To achieve this aim, school practices based on inclusive values are needed, establishing a clear and common concept of inclusive education for the entire educational community (Booth \& Ainscow, 2015).

One of the urgent issues in terms of inclusion is the management of cultural diversity: an inherent element of today's schools and one which therefore requires educational practices that meet the needs of foreign pupils 
and migrant communities (Essomba, 2006). Although social and educational policies try to promote attention to diversity from an intercultural perspective, we note that this does not always translate into practices that bring with them the principles and values of interculturality and inclusive education.

Managing cultural diversity is therefore an essential task, particularly for management teams, who must oversee a greater number of tasks, roles, and responsibilities (Rönnström \& Scott, 2019). However, some studies reveal that management of cultural diversity is left in the hands of professional specialists, falling back into deficit-centred models that emphasise the role of the expert and move away from inclusive approaches (Gómez-Hurtado et al., 2018).

The specialised literature on inclusion acknowledges the relevance of the leadership of school management teams for the development of inclusive and intercultural schools (Essomba, 2006; Morrissey, 2021). However, to date, there is insufficient evidence of effective inclusive leadership practices for managing cultural diversity. For this reason, it is interesting to add research to discuss the role of the management team in the inclusion of foreign pupils and the promotion of interculturality. To this end, the focus of this article is to highlight good practices of management teams in promoting and addressing cultural diversity, understanding this as the set of cultural differences that coexist and interact in the school and which, in the case of this study, are mainly based on the foreign population (Jiménez, 2014).

It is precisely in this current scenario that this work presents the outcomes of research which, although carried out in two distant and different geographical contexts (Santiago de Chile and Andalusia in Spain), and despite the fact that Spain has more experience and a longer track record in the migration-school relationship, share important conditions and concerns regarding the management of cultural diversity (Gurpegui \& Mainer, 2013; Jiménez \& Valdés, 2021): (1) The migratory phenomenon is consolidated in their respective education systems; (2) the absence of a universal policy for the inclusion of foreign pupils has created a scenario of self-directed response by schools; and (3) in both countries, educational measures for the attention to diversity have been affected by the gradual incorporation of market-based education, to the detriment of public education. In line with the above, it is empirically relevant to explore the practices of school leaders in managing cultural diversity. This is in addition to the fact that two research teams, one from each country, share a concern for the role that inclusive leadership plays in the implementation of educational practices that contribute to the development of interculturalism and inclusion (Valdés \& Gómez-Hurtado, 2019). It is based on this shared concern of both research teams and the interest in developing a collaborative alliance that, thanks to the funding of the respective research efforts, this study was conducted.
Using a qualitative approach and based on a multiple case study (six schools), the results allow us to understand the relationship between leadership and inclusive and intercultural practices with new empirical evidence (Section 4). Finally, Section 5 attempts to show how this international research makes an interesting contribution to the field of study between migration and school, insofar as it explores elements which, despite the abundant literature available, have not been submitted to the indepth study required.

\section{State of the Art}

\subsection{Managing Cultural Diversity in School}

Consolidation of the migratory phenomenon in current educational systems, as is the case of Spain in Europe or Chile in Latin America, combined with the diversification of nationalities of origin and the absence of formal models for cultural diversity management, has created a scenario where schools adopt a self-taught response to the issue of schooling foreign pupils (Jiménez et al., 2020). Along these lines, it is possible to point out that schools experience the inclusion of foreign pupils as a kind of "tutored abandonment" (Jiménez \& Valdés, 2021). In other words, this occurs in a scenario characterised by a lack of resources, training, and spaces for accompaniment. This self-taught effort has given rise to a set of school practices to respond to the needs of these pupils, including welcome classrooms, hiring interpreters, programmes for Spanish as a second language, interactive groups, and welcome protocols, among others (Valdés et al., 2019). Recent literature highlights that the self-taught logic in migration issues leads to a set of difficulties related to design, implementation, and evaluation. In addition, it is relegated to teachers and certain professional specialists who apply assimilationist or monocultural actions (Jiménez, 2014; Stang-Alva et al., 2021), which is why it is necessary to extend the set of school stakeholders and position school leadership as a key aspect in addressing cultural diversity.

We understand cultural diversity management from an inclusive and intercultural perspective. In other words, one that allows students belonging to majority and minority and/or foreign cultures to be brought together in the same educational context and in the same system of activity, without the need for pupils to be separated by levels or even by establishments, as in segregationist schools (Carrasco \& Coronel, 2017), or served under a compensatory logic, as in the assimilationist school (Jiménez, 2014). Thus, the school, through its commitment to the educational inclusion of all pupils, manages to appropriately and harmoniously resolve the tension presented by multicultural educational contexts between the development of comprehensiveness and attention to diversity, avoiding inequality and exclusion (Jiménez \& Valdés, 2021). 
In order to move towards a school that manages diversity interculturally, it is necessary to position management teams committed to inclusion. To this end, school leadership has been considered by the scientific community as one of the key elements to promote the development of educational improvement (Weinstein \& Muñoz, 2019). Although we are currently witnessing a political and educational moment where diversity is valued and celebrated (Ainscow, 2020), we still come up against practices and different forms of exclusion that occur in relation to the management of diversity and culture within schools. This therefore brings with it formative, paradigmatic, and cultural challenges for management teams (Gardiner \& Enomoto, 2006). In this context, it is not enough to exercise good school management, i.e., to give sustainability to the organisational conditions of an educational institution, but to advance in leadership, which is characterised by articulating and achieving shared objectives and goals with other people in the school through contextualised practices (Valdés, 2020). Thus, educational leadership should promote the development of measures to address cultural diversity in the school based on mobilisation of the educational community and collaborative working (Hajisoteriou, 2012). In this way, school management teams have the mission of becoming promoters who work to build culturally responsive schools.

School leadership as a key agent in addressing cultural diversity means that management teams are essential in developing practices that respond to and manage the needs of immigrant pupils (Andersen \& Ottesen, 2011), opting for inclusive and culturally responsible leadership that promotes the values of an inclusive society, thus fostering the development of policies of equity, equality, inclusion, and social justice (Ainscow \& Sandill, 2010; Blackmore, 2006; DeMatthews, 2015; Devine, 2013; Stevenson, 2007).

Among the practices that stand out in the construction of an inclusive school, reference is made to the collaboration of the whole community and the construction of a common meaning of inclusive education (Ainscow et al., 2006). However, we sometimes find that school managements show lack of interest in responding to cultural diversity and the development of measures that meet the needs of all students in the school, manifesting an assimilationist vision and a "false inclusion" whereby the lack of use of specific measures in favour of the inclusion of pupils is justified, preferring, on the other hand, the figure of the specialist as a professional who attends and responds to cultural diversity (Gómez-Hurtado et al., 2018), thus committing to compensatory education (Díez, 2014). From this standpoint, it is perceived that cultural diversity is not a school-wide issue (Devine, 2013; Lumby, 2006).

According to Gómez-Hurtado and Coronel Llamas (2021), school administrations should become more involved in the management of cultural diversity, which would allow the development of a school culture sensi- tive to issues related to differences and equity, where management teams set up coordination mechanisms between teachers and other educational community stakeholders involved in cultural diversity management, thus promoting that immigrant students do not feel socially and academically isolated by performing specific tasks related to their inclusion process.

The commitment to inclusive leadership can lead us to a safe path where culturally diverse students feel part of the school and are part of the processes that take place in it.

\subsection{Inclusive Leadership as a Response to Cultural Diversity}

The research takes pains to emphasise the role of leaders as essential and fully involved in promoting, designing, and implementing inclusive practices in schools (DeMatthews, Billingsley, et al., 2020; DeMatthews, Serafini, \& Watson, 2020; León, 2012; León et al., 2018; Ryan, 2016; Valdés, 2018; Valdés \& Gómez-Hurtado, 2019; Yildirim, 2021). The leadership exercised by the management team in relation to diversity management has a fundamental role to play (Ainscow \& West, 2006; Booth \& Ainscow, 2015; Fernández-Batanero \& Hernández-Fernández, 2013; Fernández-Batanero et al., 2014; Leithwood, 2005; León, 2012).

School leadership is acknowledged as a fundamental aspect in school improvement and in the consolidation of pupil learning (Ainscow \& Sandill, 2010). Leadership practices arise from interactions among school members based on common interests and the context in which they are developed (Spillane \& Ortiz, 2017). The concept of leadership practices is thus dynamic and contextualised (Uribe \& Celis, 2012), as these practices are formed through the collaboration that takes place between people in an organisation, which is why their definition is linked to the context in which they are carried out (Spillane, 2005).

The implementation of good leadership practices has led to significant processes of change and transformation in schools (Hallinger \& Heck, 2011). However, in the case of this article, we consider that school improvement must necessarily be inclusive (Valdés, 2018) and that the consolidation of pupils' curricular learning is not the only relevant dimension, especially from the point of view of inclusion and interculturality. Therefore, we are committed to the development of inclusive leadership (Valdés \& Gómez-Hurtado, 2019) that guides the management of cultural diversity, celebrates difference, advocates for diverse learners, and culturally develops the school at the personal, contextual, and curricular levels (LadsonBillings, 2014). Commitment to inclusive leadership can be a sure path to genuine and timely care for migrant communities and the rest of their members.

According to González-Falcón (2021), one of the current challenges for school management consists of becoming more involved in the management of cultural 
diversity. On occasion, we find that school administrations show a lack of interest in responding to cultural diversity and developing measures that address the needs of all pupils in the school. They rely on an assimilationist vision and a simulacrum of inclusion reinforced by the figure of the specialist as a professional who attends and responds to cultural diversity (Gómez-Hurtado et al., 2018), while settling for a compensatory education. It thus follows that cultural diversity is not a school-wide issue (Devine, 2013) and that inclusive leadership is therefore not a priority.

We share Morrissey's (2020) position that different types of leadership are necessary to build an inclusive school. The literature on good practices of inclusive leadership focuses on the fact that the actions of inclusive leaders target those pupils who present learning problems or are in priority conditions of exclusion, connect with the educational community (whether inside or outside the school), install a shared discourse of inclusion, create environments of mutual support and collaboration between teachers and non-teaching professionals, and professionally develop the people who work in the school context through training, instances of reflection and training, etc. (Glenda et al., 2014; León et al., 2018; Porakaria et al., 2015; Valdés, 2020). However, the information is less specific in relation to cultural diversity management, and it is therefore useful to provide new empirical evidence to discuss the inclusion of foreign immigrant pupils in better terms.

\section{Method}

The research presented here is part of two projects financed by competitive tenders from the countries involved (Spain and Chile). The main objective was to explore good management practices in cultural diversity and attention to immigrant pupils from an inclusive leadership perspective. The study is framed within a qualitative methodology. Specifically, through six case studies in six early childhood education and primary schools in Spain and Chile, comprising four basic schools in the metropolitan region (Chile) and two early childhood education and primary schools in Andalusia (Spain). The cases were purposively selected based on the following selection criteria: (1) their track record in practices of attention to cultural diversity and (2) the flow and enrolment of immigrant pupils in the schools. To gain access to the schools, letters of introduction were first sent out, then an initial interview was held with the school principals to explain the purpose of the study, and then the fieldwork was carried out. A case study with purposive sampling was used (Patton, 2002) with three key criteria for the selection of schools: (1) their track record in practices of attention to cultural diversity; (2) having an inclusive and intercultural educational project; and (3) a high enrolment of foreign pupils (over $30 \%$ of the total roll). The case study method was used, as according to Flick (2015) and Velasco and Díaz de Rada (2018) it has the advantage of providing greater possibilities to further the practices in the cultural manifestations of the participating spaces and allows the use of a wide range of techniques depending on the study objective.

The instruments used were developed by the two teams of researchers and validated beforehand. In the case of the individual in-depth interviews, a thematic script was prepared with topics of theoretical interest using the key dimensions of the inclusive leadership style as reference (Valdés \& Gómez-Hurtado, 2019). The interviews lasted approximately one hour, were held in the participants' workplaces and the saturation interviewing technique was used (Morse, 1995). Interviews were first conducted with formal leaders (principals and management teams) and then with informal leaders (support teachers and non-teaching professionals). In addition, participant observations took place in formal and informal spaces along with analysis of official documents (see Table 1). The research teams stayed in the schools for 12 weeks, where 36 visits were made (three per week). In the case of the interviews, the participants signed an informed consent of willingness and anonymity, documents approved by the ethics committee of the institution sponsoring the research.

For data analysis, an inductive process of analysis and coding was carried out using Atlas.ti statistical software. This categorisation and analysis process was applied by contrasting the data gathered in both research projects, deriving four common categories: (1) fostering of intermediate and informal leadership; (2) engagement in diversity management; (3) development of organisational strategies based on collaboration; and (4) developing a culture of inclusion. To meet the validity and plausibility criteria outlined by Flick (2015), we conducted a triangulation of researchers. This involves sharing the quotes and codes between the people in charge of both projects in order to minimise any over-interpretation. The result of this triangulation revealed majority agreement in the categories that will be presented in the results. In addition, the validity criterion also entails making visible the actions that the analysis has facilitated to promote transformative agency and empower educational collectives to act. This criterion is observed in the results and was confirmed after the research through a process of delivery and analysis of outcomes with the schools.

These categories, which at the same time function as shared and underlying dimensions, also make it possible to project a series of good practices, which are presented in the next section on results.

\section{Results}

In this section, we report on four dimensions common to all management team practices. We shall describe each dimension and exemplify the most relevant practices of school leaders. 
Table 1. Systematisation of data production.

\begin{tabular}{|c|c|c|c|c|c|c|c|}
\hline \multirow[b]{2}{*}{ Techniques } & \multicolumn{3}{|c|}{ Chile } & \multicolumn{3}{|c|}{ Spain } & \multirow[b]{2}{*}{ Total } \\
\hline & School 1 & School 2 & School 3 & School 4 & School 5 & School 6 & \\
\hline Individual interviews & 6 & 6 & 7 & 4 & 8 & 8 & 39 \\
\hline Participant observations & 16 & 16 & 16 & 12 & 24 & 24 & 108 \\
\hline Documents reviewed & 2 & 1 & 1 & 3 & 1 & 1 & 9 \\
\hline
\end{tabular}

\subsection{Fostering Intermediate and Informal Leaderships}

This dimension refers to a set of practices related to the professional development of the community with a defined focus on inclusion and interculturality and based on the promotion of informal leaders, intermediate leaders-defined as individuals embodying roles of both leader and follower-and other relevant actors for decision making within the school space. Some of the most common practices are as follows: hiring people with an inclusive profile, placing good teachers in conflictive courses, detecting talents and taking advantage of them for the organisation, managing skills training for teaching and non-teaching professionals, and encouraging emergent and informal leaderships. This last point is particularly key for cultural diversity management in the participating schools and should be emphasised. The management teams from the six schools promote the positioning of the professionals involved in the inclusion of foreign pupils.

The role of teachers who teach Spanish to immigrants in Spain (hereinafter ATAL teachers) or special education teachers in Chile is highlighted as an essential element in the educational response to foreign pupils. The management teams agree on a positive assessment of the functions to be performed by these teachers with foreign pupils. The ATAL teacher in Spain is a reference for immigrant pupils, "a very important reference for them; even some non-immigrants want to go to the ATAL teacher," said a teacher (school 5). They tend to be professionals who are actively involved in the response to immigrant pupils and lead or participate in tasks. These include adaptation of foreign pupils to the school, didactic and linguistic support in the specific classroom or in regular classrooms, and mediation with families. The actions carried out by these teachers are supervised and supported by the management team: "The ATAL teacher acts as a key connector between the different teachers and the community to promote intercultural actions" (principal, school 6). The special education teacher in Chile is also a relevant reference, as in the absence of a national strategy to address cultural diversity, special education teachers make their knowledge, resources, and schedules available to migrant pupils, with the support of the principal and the head of the technical teaching unit: "The specialist teacher is providing a lot of support there with the migrant children, with their assessment, in the collaborative work with psychologists and psychopeda- gogues; the group of special education teachers gives us a lot of support there" (principal, school 1).

As we were able to demonstrate in both countries, in these schools there is a characteristic appearance of key intermediate leadership in the work with immigrant pupils. In the case of Chile, in the work of special education teachers, and in Spain, of the ATAL teachers. Despite the empowerment of these professionals, there is a risk that, in some cases, they may represent a model of experts in the face of diversity, which would imply an individual and specific response rather than a collective and inclusive one.

\subsection{Involvement in Diversity Management}

This dimension brings together a series of practices aimed at making differences visible, making resources available to the community, addressing needs from a pedagogical perspective, celebrating diversity, and implementing actions to compensate for curricular gaps or needs of foreign pupils. In the case of a Chilean school, the creation of a reception classroom, created and installed by the principal and coordinated by the head of the technical unit, is noteworthy. The reception or welcome classroom corresponds to the creation of a specific space for learning the schools' vehicular language. It is managed by a teacher of Dominican-Haitian origin. It is a device designed for students who have not been previously enrolled in our education system and who consequently have a very poor command of Spanish, a situation that prevents them from following the normal educational processes in their respective classrooms. As the principal from school 2 points out: "It is a strategy that helps improve core curricular learning and she [the Haitian teacher] works in coordination with the technical director."

In the case of Spain, the actions promoted by school management to encourage the collaboration and participation of immigrant families in schools are highlighted. Among them, coordination with the school parents' association to organise training activities to meet the needs and demands of immigrant families (learning Spanish, cultivation of the mother tongue, computer literacy, etc.), advice on functioning and formulas for participation in schools, the holding of intercultural days or weeks, or the creation of the figure of a parent tutor in class to support pedagogical actions: "In the promotion and development of actions with immigrant families, the 
ATAL teacher continues to be a key figure, who mediates between them and the school families' association or the management team" (field note 7, school 6).

In both countries, the management team is concerned with trying to improve the educational attention given to immigrant pupils and increasing the pedagogical and human resources that make it possible to better manage cultural diversity. The approach continues to rely on ATAL teachers, but also promotes the collaboration and participation of families. However, the compensatory actions aimed at immigrant pupils and their families stand out more than those based on their experiential and cultural background. Opportunities that positively manage cultural diversity and contribute to the promotion of inclusion and interculturality among all members of the educational community are thus lost (González-Falcón, 2021).

\subsection{Development of Collaboration-Based Organisational Strategies}

This dimension refers to a set of collaborative practices and strategies designed to address cultural diversity in schools. They are driven and coordinated by school management, as they affect bureaucratic structures and educational management. Some of the most representative actions are as follows: schools open to the community, support networks, intercultural teacher assessment guidelines, and welcoming protocols, among others.

One of the most important common actions promoted by the management teams in Spanish and Chilean schools is the development of reception plans and protocols that respond to the needs of foreign pupils arriving at the school. In the development of these plans/protocols, both the linguistic facilitators in the case of Chile and the ATAL teacher in the case of Spain play a fundamental role as the educational and emotional link between the school and the child who joins the centre. The management teams develop internal links with certain educational agents that coordinate specific actions in the educational process. The protocols are an internal institutional management tool that takes care of culturally diverse pupils and both their design and execution call for tasks and roles of different school professionals (such as psychologists, intercultural mediators, or social workers, etc.). The following quote is from a social worker who participated in the creation of a protocol:

You see, there are several parts. There is a part that is purely administrative and which has to serve as a kind of guide to what should be done by someone who has just arrived in this country with the intention to stay. Then you talk to them about visas, consulates, documentation....Apart from that, there are their rights, with the possibility of being a priority, with the right they have, and on the other hand, there is the educational issue, which has to do with the fact that the children arrive and we have to see what level they should go into, if they have their studies legalised, and all of this is overseen by the head of the technical unit. (social worker, school 1)

The organisational strategies of the management teams operate not only internally, but also with different outside agents, which corresponds to another of the concrete actions promoted by the management teams to attend to cultural diversity. The participation of associations, local authorities, delegations, NGOs, and universities means the creation of collaboration networks that allow better attention and response to the needs of foreign pupils: "We have a close relationship with associations; we work very well with the city council, the social services as well, although in terms of actions, you could say they were more of a cultural nature" (counsellor, school 5). In addition, the management teams are committed to creating meeting spaces where aspects related to intercultural issues are reviewed. The main actors are the teaching staff, ATAL teachers, the management team, and the school guidance counsellors.

The development of collaboration strategies with different internal and external agents is undoubtedly one of the main concerns of the management teams in both countries. In Spain there is a more consolidated network in this sense, also fostered by greater institutional support than in Chile. Headway is being made, particularly in the creation of schooling and educational care protocols, although in the participation processes there is less involvement of pupils and families, and the issues are less focused on the celebration of cultural diversity.

\subsection{Developing a Culture of Inclusion}

This dimension brings together a series of discourses and practices that seek to prioritise inclusive values (such as trust, fairness, and respect) in school decisions, work in community and create a healthy and safe environment for professional development. This is especially evident in the concerns that management teams have about addressing diversity. In other words, leaders defend certain school practices because of the values involved. Values such as rights, love, honesty, and trust were particularly promoted by the management team of a Chilean school and accepted and supported by the rest of the staff:

Yes, the human quality of the people, the collaborative work, the complementary nature of everything, because we all have to take care of everything, you know? We all have the confidence to address a superior....It is a very trusting job, very much a team effort, and if something doesn't work out, we are very selfcritical; since the work was everyone's responsibility, never blaming anyone. And they always approach it as a way to improve. (head of technical unit, school 4)

The principal of one of the schools' notes: "Promoting values is also worked upon in the pedagogical area" (field 
note 1 , school 3). This implies that even the most technical decisions, such as curricular adaptations, are guided by values, especially those related to the school's educational project.

The promotion of inclusive values and principles is also present in the Spanish schools analysed. In both cases, there are direct allusions to this in the educational and management projects of both schools. As stated by one of the principals (school 6): "We advocate the promotion of empathy, altruism, and equity, as they are indispensable for an inclusive school." In this sense, the number of complementary activities related to education in values is noteworthy and, specifically in one of the schools, the implementation of specific initiatives for the development of prosocial behaviour among the pupils. In them, pupils voluntarily help each other to achieve different academic, sports, cultural or leisure, and free time objectives (explaining content, teaching chess, playing instruments, teaching cooking, etc.). In this way, friendly relationships among peers are encouraged, not from a strictly academic point of view, and collaboration inside and outside the school is promoted, a factor which, as we will see below, constitutes a cornerstone of the inclusive school.

\section{Discussion}

The question of how to manage cultural diversity from the perspective of inclusive leadership opens up a suggestive set of discussions of a different kind. We have organised them along three axes: discussions of a theoretical-conceptual nature, of a practical-projective nature, and of a methodological nature.

First, the results show that, despite the abundant educational research currently available, it is necessary to delve deeper into the different forms of collaboration that are established in schools. The self-taught logic that characterises the response of Chilean schools not only operates at the institutional level but is also replicated in certain actor-professionals who also, on their own individual initiative, make decisions related to cultural diversity management and implement strategies for its improvement. This raises a troubling tension between an approach focused on collaborative leadership and professional encapsulation. As Erausquin and D’Árcangelo (2018) point out, professional encapsulation can become extremely harmful if it becomes entrenched in the school culture, insofar as it does not consider the multiplicity of voices that characterises the school as a system of activity (Sannino et al., 2016). As we have presented, there are practices that are in line with collaborative work where different professional voices converge, practices that require maximum acknowledgement if they are to be maintained and expanded to other dimensions of school management.

In relation to the above, it is not only necessary to strengthen internal forms of collaboration, in which leadership is clearly key, but also to complement them with external forms of collaboration. As Chaiklin and Hedegaard (2013) represent with the three quarters metaphor, educational agents do not necessarily have all the knowledge, skills, or procedures necessary to bring about the transformations that the reality of each school poses in a situated manner. Thus, the necessary completeness (the remaining quarter) is obtained by working together with other professionals, through the construction of relational agencies (Yamazumi, 2009). In this sense, and from a comparative discussion of the results, if there is something that the Chilean school should learn from the Spanish school it is precisely its capacity to link itself with its surroundings, forge alliances with other schools in the district, set up channels of collaboration with universities, and so forth. This type of inter-professional agencies that give rise to the emergence of new inclusive leaderships are key to better respond to the educational needs of pupils belonging to foreign minorities.

Second, in order to move towards a more transformative model of research that goes beyond a merely descriptive contribution, we define the practical actions that can have an impact on the reality of the schools examined. In this sense, and always from the standpoint of inclusion as a process in continuous development (Ainscow, 2020), the analyses carried out allow us to highlight some significant achievements, as well as the need to advance towards more inclusive management practices. In all schools, both Spanish and Chilean, intermediate leadership stands out. The management teams have been able to deploy different actions to collaborate with other internal and external agents and delegate their leadership to other members of the educational community. Specialist teachers stand out, and especially Spanish teachers, who-even in collaboration with others-centralise these functions. Although their role is considered a key factor in the inclusion of immigrant pupils and the promotion of interculturality, it is necessary to emphasise the participation and leadership of other teachers and informal leaders, such as families and pupils themselves (González-Falcón, 2021). In this regard, it is pertinent that management teams make progress in talent detection, beyond the teaching staff, to support inclusive pedagogical practices. Practices that cannot consider only compensatory proposals that would reinforce the deficit theory (Gómez-Hurtado et al., 2018), but must also foster a positive conception of diversity, acknowledging the contributions that everyone can make to improve educational and inclusive processes. In this respect, it is important not only to increase the material and human resources from outside the school, but also to train teachers and members of the educational community themselves in order to empower them as innovative and transforming agents of their own contexts. From the school management, and as supported by the specialised literature, ongoing training programmes on inclusive intercultural competencies aimed at teachers and the rest of the community could be promoted. This way, progress could also be made in 
the active participation of pupils and families. Not only in the different schooling protocols and programmes for educational attention to immigrant pupils, but especially in the formulation of an authentic inclusive culture. Participation would assume its most systemic formulation, advancing from collaboration with teachers to the formulation of proposals, initiative taking, and leadership of pupils and families. Participation is advocated not only in academic aspects but also in collaborative networks with the territory and in which the diversity of routes, processes, experiences, languages, and cultures of the school is celebrated as a value to be highlighted for the school and its community.

Third, from a methodological point of view, we believe that the study of leadership in educational inclusion needs to move towards a more participatory research format (Nind, 2017) that not only considers the school actors as research subjects, but also as active participants in the research, as co-constructors. Although our respective data production processes involved the participation-and voice-of students, teachers, and other education professionals, they were not involved in the research design or data analysis. We consider this a challenge for future research from an ethical-political perspective, as we must leave the logic of extractive investigation behind in order to move towards a more participatory kind of research. This is not only because of an ethical-political issue that is undoubtedly currently gathering momentum, leaving behind the logic of extractive research, but also because it enhances the quality of the data produced (Muñoz-Proto et al., 2020). The voices, approaches, and points of view of the members of the educational community are better incorporated and processes of reflection, self-evaluation and transformation are encouraged. Processes that will become more systemic and systematic with other complementary formulas such as shadowing, and which go beyond the textuality of the speeches and the emic perspective of participant observations. Formulas, in short, that make it possible to include the school's day-to-day activities, spontaneity, and the emergent and unscheduled tasks of the principals.

\section{Conclusions}

The research carried out has revealed some of the key factors linked to the development of inclusive leadership in cultural diversity management. The importance of school management and various leaders in promoting a collaborative inclusive culture, the development of organisational and didactic strategies based on the recognition and participation of the educational community and the commitment of schools to social justice, prosocial behaviours, and values such as friendship and companionship are emphasised. Management teams are increasing their strategies and commitments in favour of educational inclusion, although it is still necessary to be attentive to practices that may degenerate into mere compensation and the sole action of specialists. In this sense, the commitment to the articulation of collaboration and cooperation networks with the different members of the educational community is clear. The participation of families and, especially, of immigrant pupils in schools, is a priority focus in cultural diversity management. In this sense, management teams should emphasise educational practices focused on the knowledge and cultural capital of foreign pupils, as well as on the recognition and celebration of cultural diversity (González-Falcón, 2021). The school must reinforce its role as a promoter of equality, culture, education, and social justice, as pointed out and reinforced by Theoharis (2007). The school must reinforce its role as a promoter of equality, culture, education, and social justice. It must stimulate processes of social and educational change and transformation, and in this task the role of management teams continues to be fundamental.

In this regard, we also call for a more proactive role of the academic community, committed to a twofold dimension: (1) formative research (Englund \& Price, 2018) on the one hand, anchored locally and whose results can be put at the service of school improvement in the same context in which they were produced (Jiménez et al., 2017) and (2) comparative analyses on the other hand that help, not to generalise results, but rather to further the understanding and keys to the phenomena studied. In short, researching and acting from a more participatory, inclusive, inter-professional, and transformative perspective. Research conducted from this perspective will contribute to our knowledge of leadership and inclusion, and to the discussion on the preparation and training of inclusive leaders (DeMatthews, 2015).

\section{Acknowledgments}

We are deeply grateful to the editors and unknown reviewers of this article for the valuable comments we received for writing this article. We would also like to thank the Spanish Ministry of Economy and Competitiveness (project CSO2013-43266- $R$ "Construyendo diferencias en la escuela. Estudios de las trayectorias de las ATAL en Andalucía, de su profesorado y de su alumnado") who supported the research and the National Research and Development Agency (ANID) through the National Scientific and Technological Research Commission (CONICYT; Fondecyt projects 1190349 and 3200192). This article was translated by Neil Macowan Language Services.

\section{Conflict of Interests}

The authors declare no conflict of interests.

\section{References}

Agenda 2030. (2015). Objetivos del desarrollo sostenible [Sustainable development goals]. https:// 
www.agenda2030.gob.es/objetivos/home.htm

Ainscow, M. (2020). Promoting inclusion and equity in education: Lessons from international experiences. Nordic Journal of Studies in Educational Policy, 6(1), 7-16. https://doi.org/10.1080/20020317.2020. 1729587

Ainscow, M., \& Sandill, A. (2010). Developing inclusive education systems: The role of organisational cultures and leadership. International Journal of Inclusive Education, 14(4), 401-146. https://doi.org/ 10.1080/13603110802504903

Ainscow, M., \& West, M. (2006). Improving urban schools. Leadership and collaboration. Open University Press; McGraw-Hill Education.

Ainscow, M., Booth, T., \& Dyson, A. (2006). Improving schools, developing inclusion. Routledge.

Andersen, F. C., \& Ottesen, E. (2011). School leadership and ethnic diversity: Approaching the challenge. Intercultural Education, 22(4), 285-299. https://doi. org/10.1080/14675986.2011.617422

Blackmore, J. (2006). Deconstructing diversity discourses in the field of educational management and leadership. Educational Management Administration \& Leadership, 34(2), 181-199. https://doi.org/ $10.1177 \% 2 F 1741143206062492$

Booth, T., \& Ainscow, M. (2015). Guía para la educación inclusiva. Desarrollando el aprendizaje y la participación en los centros escolares [Guide for inclusive education. Developing learning and participation in schools]. FUHEM; OEI.

Carrasco, M. J., \& Coronel, J. M. (2017). Percepciones del profesorado sobre la gestión de la diversidad cultural: Un estudio cualitativo [Teachers' perceptions on the management of cultural diversity: A qualitative study]. Educación XXI: Revista de la Facultad de Educación, 20(1), 75-98.

Chaiklin, S., \& Hedegaard, M. (2013). Cultural-historical theory and educational practice: Some radical-local considerations. Nuances: Estudos sobre Educação, 24(1), 30-44. http://revista.fct.unesp.br/index.php/ Nuances/article/view/2151/seth

DeMatthews, D. (2015). Making sense of social justice leadership: A case study of a principal's experiences to create a more inclusive school. Leadership and Policy in Schools, 14(2), 139-166. https://doi.org/ 10.1080/15700763.2014.997939

DeMatthews, D., Billingsley, B., Mcleskey, J., \& Sharma, U. (2020). Principal leadership for students with disabilities in effective inclusive schools. Journal of Educational Administration, 58(5), 539-554, https://doi. org/10.1108/JEA-10-2019-0177

DeMatthews, D., Serafini, A., \& Watson, T. N. (2020). Leading inclusive schools: Principal perceptions, practices, and challenges to meaningful change. Educational Administration Quarterly, 13, https://doi.org/ 10.1177\%2F0013161X20913897

Devine, I. (2013). Practising leadership in newly multiethnic schools: Tensions in the field? British Journal of Sociology of Education, 34(3), 392-491. https:// doi.org/10.1080/01425692.2012.722273

Díez, E. J. (2014). La práctica educativa intercultural en Secundaria [Intercultural educational practice in secondary school]. Revista de Educación, 363, 12-34. http://dx.doi.org/10.4438/1988-592X-RE-2012-363168

Englund, C., \& Price, L. (2018). Facilitating agency: The change laboratory as an intervention for collaborative sustainable development in higher education. International Journal for Academic Development, 23(3), 192-205. https://doi.org/10.1080/1360144X. 2018.1478837

Erausquin, C., \& D’Árcangelo, M. (2018). Unidades de Análisis para la construcción de conocimientos e intervenciones en escenarios educativos [Analysis units for the construction of knowledge and interventions in educational settings]. In C. Erausquín (Ed.), Interpelando entramados de experiencias. Cruce de fronteras e implicación psico-educativa entre universidad y escuelas [Questioning webs of experiences. Border crossing and psycho-educational involvement between university and schools] (pp. 1-25). EDULP.

Essomba, A. (2006). Liderar escuelas interculturales $e$ inclusivas. Equipos directivos y profesorado ante la diversidad cultural y la inmigración [Leading intercultural and inclusive schools. Management teams and teachers in the face of cultural diversity and immigration]. Editorial Graó.

Fernández-Batanero, J. M., \& Hernández-Fernández, A. (2013). El liderazgo como criterio de calidad en la educación inclusiva [Leadership as a quality criterion in inclusive education.]. Estudios sobre educación, 24, 83-102. https://revistas.unav.edu/index. php/estudios-sobre-educacion/article/view/2025

Fernández-Batanero, J. M., Reyes, M. M., Japón, D., \& Piñero, R. (2014). Liderazgo inclusivo. Un estudio de casos en Andalucía [Inclusive leadership. A case study in Andalusia; Communication]. XI Congreso Internacional y XXXI Jornadas de Universidades y Educación Inclusiva, Sevilla, Spain [XI International Congress and XXXI Conference Cycles on Universities and Inclusive Education]. http://www.quadernsdigitals. net/datos_web/hemeroteca/r_77/nr_843/a_11332/ 11332.pdf

Flick, U. (2015). Introducción a la investigación cualitativa [Introduction to qualitative research]. Morata.

Gardiner, M. E., \& Enomoto, E. K. (2006). Urban school principals and their role as multicultural leaders. Urban Education, 41(6), 560-584.

Glenda, J., Eloff, I., \& Moen, M. C. (2014). How inclusive education is understood by principals of independent schools. International Journal of Inclusive Education, 18(5), 535-552. http://doi.org/10.1080/ 13603116.2013.802024

Gómez-Hurtado, I., \& Coronel Llamas, J. M. (2021). Dirección escolar y liderazgo inclusivo. Celebrando la diversidad cultural [School management and inclu- 
sive leadership. Celebrating cultural diversity]. In I. González-Falcón (Ed.), Atención a la diversidad cultural en el contexto educativo. Claves y desafíos para la escuela inclusive [Attention to cultural diversity in the educational context. Keys and challenges for the inclusive school] (pp. 63-72). Pirámide.

Gómez-Hurtado, I., González-Falcón, I., \& Coronel, J. M. (2018). Perceptions of secondary school principals on management of cultural diversity in Spain. The challenge of educational leadership. Educational Management, Administration \& Leadership, 46(3), 441-456. https://doi.org/10.1177\%2F17411 43216670651

González-Falcón, I. (Ed.). (2021). Atención a la diversidad cultural en el contexto educativo. Claves y desafíos para la escuela inclusiva [Attention to cultural diversity in the educational context. Keys and challenges for the inclusive school]. Pirámide.

Gurpegui, J., \& Mainer, J. (2013). La crisis de la escuela como problema: Modos de educación, crítica de la crítica y formas de resistencia [The crisis of the school as topic: Modes of education, criticism of criticism and forms of resistance]. Con-Ciencia Social, 17, 13-26. http://www.fedicaria.org/encuentros/ XV-MADRID-2013.htm

Hajisoteriou, C. (2012). Listening to the winds of change: School leaders realizing intercultural education in Greek-Cypriot schools? International Journal of Leadership in Education, 15(3), 311-329. https://doi.org/ 10.1080/13603124.2011.605473

Hallinger, P., \& Heck, R. (2011). Conceptual and methodological issues in studying school leadership effects as a reciprocal process. School Effectiveness \& School Improvement, 22(2), 149-173. https://doi.org/ 10.1080/09243453.2011.565777

Jiménez, F. (2014). Modelos de gestión de la diversidad cultural para la escolarización de alumnado inmigrante en las escuelas chilenas: Desafíos para la interculturalidad actual [Models of cultural diversity management for the schooling of immigrant students in Chilean schools: Challenges for current interculturality]. Estudios pedagógicos, 40(2), 409-426. https:// dx.doi.org/10.4067/S0718-07052014000300024

Jiménez, F., \& Valdés, R. (2021). Políticas y prácticas inclusivas para estudiantes extranjeros en contextos de neoliberalismo avanzado: Paradojas y contrasentidos del caso emblemático chileno [Inclusive policies and practices for foreign students in contexts of advanced neoliberalism: Paradoxes and contradictions of the Chilean emblematic case]. Educar, 57(82), 1-27.

Jiménez, F., Fardella, C., \& Muñoz-Proto, C. (2017). Una aproximación microetnográfica de prácticas pedagógicas en escuelas multiculturales. Tensiones y desafíos en torno a la escolarización de inmigrantes y grupos minoritarios [A microethnographic approach to pedagogical practices in multicultural schools. Tensions and challenges around the schooling of immigrants and minority groups]. Perfiles educa- tivos, 39(156), 72-88. http://www.scielo.org.mx/ scielo.php?script=sci_arttext\&pid=S0185-

26982017000200072\&lng=es\&tlng=

Jiménez, F., Valdés, R., Hernández-Yáñez, M. T., \& Fardella, C. (2020). Dispositivos lingüísticos de acogida, aprendizaje expansivo e interculturalidad: Contribuciones para la inclusión educativa de estudiantes extranjeros [Host linguistic devices, expansive learning and interculturality: Contributions for the educational inclusion of foreign students]. Educação e Pesquisa, 46. https://doi.org/10.1590/S1678-463 4202046218867

Ladson-Billings, G. (2014). Culturally relevant pedagogy 2.0: A.K.A. the remix. Harvard Educational Review, 84(1), 74-84. https://psycnet.apa.org/doi/ 10.17763/haer.84.1.p2rj131485484751

Leithwood, K. (2005). Understanding successful principalship: Progress on a broken front. Journal of Educational Administration, 43(6), 619-629.

León, M. J. (2012). El liderazgo para y en la escuela inclusiva [Leadership for and in the inclusive school]. Education Siglo XXI, 30(1), 133-160. https://revistas.um. es/educatio/article/view/149181

León, M. J., Crisol, E., \& Moreno, R. (2018). Las tareas del líder inclusivo en centros educativos de zonas desfavorecidas y favorecidas [The tasks of the inclusive leader in educational centers in disadvantaged and favored areas]. Revista Iberoamericana sobre Calidad, Eficacia y Cambio en Educación, 16(2), 21-40. https://doi.org/10.15366/reice2018.16.2.002

Lumby, J. (2006). Conceptualizing diversity and leadership. Evidence from 10 cases. Educational Management Administration \& Leadership, 34(2), 151-165. https://doi.org/10.1177\%2F1741143206062487

Morrissey, B. (2021). Theorising leadership for inclusion in the Irish context: A triadic typology within a distributed ecosystem. Management in Education, 35(1), 22-31. https://doi.org/10.1177\%2F089 2020620942507

Morse, J. (1995). The significance of saturation. Qualitative Health Research, 5(2), 147-149. https://doi.org/ 10.1177/104973239500500201

Muñoz-Proto, C., Ancapichún, A., \& Squella, R. (2020). Designing a narrative study of nonviolence centered on listening: The ethical, technical, and methodological challenges of working with life stories of social struggle in Chile. EMPIRIA. Revista de Metodología de Ciencias Sociales, 45, 143-163.

Nind, M. (2017). The practical wisdom of inclusive research. Qualitative Research, 17(3), 278-288. https://doi.org/10.1177\%2F1468794117708123

Patton, M. Q. (2002). Qualitative research and evaluation methods. SAGE.

Porakaria, J., Sevala, B., Miniti, P., Saemane, G., Sharma, U., \& Forlin, C. (2015). Solomon Islands school leaders readiness for inclusive education. International Journal of Inclusive Education, 19(8). http://doi.org/ 10.1080/13603116.2015.1013999 
Rönnström, N., \& Scott, P. (2019). Lideres escolares, maestros de la complejidad. In J. Weinstein \& G. Muñoz (Eds.), Liderazgo en escuelas de alta complejidad sociocultural. Diez Miradas [Leadership in schools of high sociocultural complexity. Ten looks] (pp. 11-152). Ediciones Universidad Diego Portales.

Ryan, J. (2016). Un liderazgo inclusivo para las escuelas [Inclusive leadership for schools]. In J. Weinstein (Ed.), Liderazgo educativo en la escuela: Nueve miradas [Educational leadership at school: Nine glances] (pp. 177-204). Ediciones Universidad Diego Portales.

Sannino, A., Engeström, Y., \& Lemos, M. (2016). Formative interventions for expansive learning and transformative agency. Journal of the Learning Sciences, 25(4), 599-633. https://doi.org/10.1080/10508406. 2016.1204547

Spillane, J. (2005). Distributed leadership. The Educational Forum, 69, 141-150. https://doi.org/10.1080/ 00131720508984678

Spillane, J., \& Ortiz, M. (2017). Perspectiva distribuida del liderazgo y la gestión escolar: Implicancias cruciales [Distributed perspective of school leadership and management: Crucial implications.]. In J. Weinstein (Ed.), Liderazgo educativo en la escuela: Nueve miradas [Educational leadership at school: Nine looks] (pp. 155-174). Ediciones Universidad Diego Portales.

Stang-Alva, M. F., Riedemann-Fuentes, A. M., StefoniEspinoza, C., \& Corvalán-Rodríguez, J. (2021). Narrativas sobre diversidad cultural y migración en escuelas de Chile [Narratives on cultural diversity and migration in schools in Chile]. Magis, Revista Internacional de Investigación en Educación, 14, 1-32. https://doi. org/10.11144/Javeriana.m14.ndcm

Stevenson, H. P. (2007). A case study in leading schools for social justice: When morals and markets collide. Journal of Educational Administration, 45(6), 769-781. http://doi.org/10.1108/09578230710829 937

Theoharis, G. (2007). Social justice educational leaders and resistance: Toward a theory of social justice leadership. Educational Administration Quarterly, 43(2), 221-258.

Uribe, M., \& Celis, M. (2012). Desarrollo de capacidades para un liderazgo escolar efectivo: Del levantamiento de competencias al reconocimiento de buenas prácticas [Capacity development for effective school leadership: From the lifting of competences to the recog- nition of good practices]. In J. Weinstein \& G. Muñoz (Eds.), ¿Qué sabemos sobre los directores de escuela en Chile? [What do we know about school principals in Chile] (pp. 111-134). Pontificia Universidad Católica de Chile.

Valdés, R. (2018). Liderazgo inclusivo: La importancia de los equipos directivos en el desarrollo de una cultura de la inclusión [Inclusive leadership: The importance of management teams in developing a culture of inclusion]. Revista de Investigación Educativa de la REDIECH, 9(6), 51-66. https://www.rediech.org/ojs/ 2017/index.php/ie_rie_rediech/article/view/73

Valdés, R. (2020). Prácticas de liderazgo en escuelas con alta y baja cultura escolar inclusiva [Leadership practices in schools with high and low inclusive school culture]. Revista Latinoamericana de Educación Inclusiva, 14(2), 213-227. http://dx.doi.org/ 10.4067/S0718-73782020000200213

Valdés, R., \& Gómez-Hurtado, I. (2019). Competencias y prácticas de liderazgo escolar para la inclusión y la justicia social [School leadership competencies and practices for inclusion and social justice]. Perspectiva Educacional, 58(2), 47-68. https://dx.doi.org/ 10.4151/07189729-vol.58-iss.2-art.915

Valdés, R., Jiménez, F., Hernández, M. T., \& Fardella, C. (2019). Dispositivos de acogida para estudiantes extranjeros como plataformas de intervención formativa [Reception devices for foreign students as platforms for training intervention]. Estudios pedagógicos, 45(3), 261-278. https://dx.doi.org/ 10.4067/S0718-07052019000300261

Velasco, H., \& Díaz de Rada, A. (2018). La lógica de la investigación etnográfica. Un modelo de trabajo para etnógrafos de escuela [The logic of ethnographic research. A working model for school ethnographers]. Editorial Trotta.

Weinstein, J., \& Muñoz, G. (Eds.). (2019). Liderazgo en escuelas de alta complejidad sociocultural. Diez miradas [Leadership in schools of high sociocultural complexity. Ten looks]. Ediciones Universidad Diego Portales.

Yamazumi, K. (2009). Expansive agency in multi-activity collaboration. In A. Sannino, H. Daniels, \& K. Gutiérrez (Eds.), Learning and expanding with activity theory (pp. 212-227). Cambridge University Press.

Yildirim, E. (2021). Inclusive leadership and counselling in schools: Asylum seekers students. Journal of Qualitative Research in Education, 25, 126-150. http:// doi.org/10.14689/enad.25.6

\section{About the Authors}

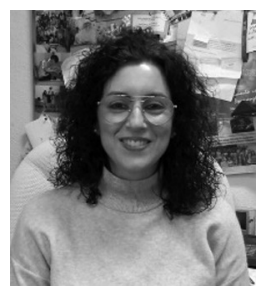

Inmaculada Gómez-Hurtado is an associate professor in the area of Didactics and School Organization of the Faculty of Education, Psychology and Sports Sciences of the University of Huelva. Her main lines of research are developed in the field of inclusive education, inclusive leadership, attention to diversity, and teaching innovation in primary education. 

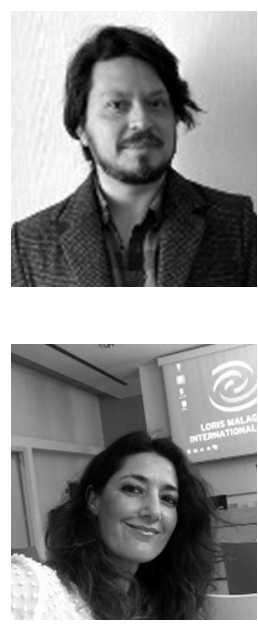

Inmaculada González-Falcón is an associate professor in the area of didactics and school organization in the Faculty of Education, Psychology and Sports Sciences, at the University of Huelva. Her main lines of research are developed in the field of intercultural education, inclusive leadership, and teaching innovation in early childhood education.

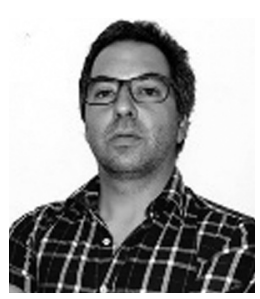

Felipe Jiménez Vargas is a researcher who studies migratory processes within the school system from a historical-cultural approach. The research carried out to date has informed the educational administration of the main difficulties in the schooling of non-Hispanic speaking students and of the main strategies developed by the educational communities. His line of research has provided tangible inputs for multi-level culture-related decision-making. 